\title{
Use of magnetic resonance imaging in equine lameness diagnosis
}

\author{
J. H. Foreman \\ University of Illinois, College of Veterinary Medicine, Department of Veterinary Clinical Medicine, Urbana, USA
}

\begin{abstract}
Summary
Magnetic resonance imaging (MRI) has been used for skeletal and central nervous system imaging in humans for years. It is currently the imaging modality of choice for examination of soft tissue intraarticular injuries such as ligament and meniscal damage. Equine studies have been performed in cadaver specimens of the carpus, metacarpophalangeal joint, femorotibial/femoropatellar joints, flexor tendons, and foot. Current technology provides diagnostic images but does not allow in vivo imaging of horses. Newer technology may allow imaging of distal limbs in standing, sedated horses.
\end{abstract}

Keywords: $\quad$ horse, magnetic resonance imaging, lameness, orthopaedics

\begin{abstract}
Die Anwendung der Kernspintomographie im Rahmen der Lahmheitsdiagnostik beim Pferd
Die Kernspintomographie wird seit Jahren beim Menschen zur Darstellung des Skelettes und des zentralen Nervensystems eingesetzt. Sie ist zur Zeit die Methode der Wahl bei der Untersuchung von intraartikulären Weichteilverletzungen wie Bänder- und Meniskusschäden. Untersuchungen im Pferdebereich wurden an Präparaten des Karpus, metacarpophalangealen Gelenks, Femorotibial- und Femoropatellargelenks, der Beugesehnen und des Fußes toter Pferde durchgeführt. Mit der derzeitigen Technologie können Darstellungen zur Diagnose erzeugt werden, aber es ist keine Untersuchung lebender Pferde möglich. Neue Technologien eröffnen die Möglichkeit, die distalen Gliedmaßen stehender, sedierter Pferde zu untersuchen:
\end{abstract}

Schlüsselwörter: Pferd, Kernspintomographie, Lahmheit, Orthopädie

\section{Introduction}

Magnetic resonance imaging (MRI) has been described for use in human medicine for over two decades (Weisman et al. 1972). The most valuable application of MRI might be in musculoskeletal imaging. For instance, it now seems to be the imaging modality of choice in examining soft tissue damage (e.g., cruciate ligaments, menisci) in injured knee joints (Kean et al. 1983) in football and basketball players.

\section{Principles of MRI}

All atoms with differing numbers of protons and neutrons have intrinsic magnetic spin properties. These atoms with spin produce an electrical current which results in an intrinsic magnetic field (Schild 1990). Because hydrogen is abundant in most mammalian tissues (as $\mathrm{H}_{2} \mathrm{O}$ ), its spin characteristics are relied upon most often in MRI.

A magnet surrounding the tissue creates an external magnetic field which causes the hydrogen protons to align themselves with the direction of the magnetic field. When an external field at the appropriate frequency is switched on and off, the result is a radiofrequency (rf) pulse. At the conclusion of the if pulses, the tissue protons return to their original configuration. The rate at which this occurs is tissue-dependent and is called the relaxation time. This aligning and relaxing of protons in synchronisation with the if pulse is detected by the MRI instrument, and provides information from which images are computed.

In response to the rf pulses, each tissue produces discrete signals which can be unique and thus allow MRI to more readily discern between different tissues (e.g., zones of cartilage) which on radiography appear to be of a similar density (e.g., all cartilage appears as soft tissue density radiographically). Tissue-dependent signal intensities are detected externally and computer-processed to create a magnetic resonance (MR) image. Two- and three-dimensional images can be computer-reconstructed from MRI (Lauterbur 1973).

\section{Previous equine research}

Magnetic resonance imaging has been used in the equine metacarpophalangeal joint (Park et al. 1987; Martinelli 1995), flexor tendon (Crass et al. 1992), foot (Denoix et al. 1993), carpus (KaserHotz et al. 1994), and femorotibial/femoropatellar joints (Holcombe et al. 1995). All of these MRI studies were performed in recentlyharvested cadaver specimens of limited numbers $(<10$ specimens per study). In some studies, excellent correlations have been shown between ultrasonographic (Crass et al. 1992) or histologic (Martinelli 1995) sections and MR images obtained post-mortem. Limited work is available in diseased limbs, but initial studies demonstrate that MR can document considerable pathological changes which are not always readily-discernible by more traditional diagnostic methods such as arthroscopy (Martinelli 1995).

\section{Advantages of MRI}

Magnetic resonance provides excellent visualisation of soft tissue structures not easily imaged by radiography. Ultrasonography 
and $\mathrm{MRI}$ are probably similar in imaging detail in soft tissue flexorsurface structures such as the flexor tendons and suspensory ligament (Crass et al. 1992). Magnetic resonance allows soft tissue images of articular cartilage not readily visualised by radiography and ultrasonography (Sabiston et al. 1987; Martinelli 1995). Zones of articular cartilage can be imaged by MRI alone (Lehner et al. 1989; Modl et al. 1991). The only other definitive methods of determining the depth of an articular lesion are by direct probing via arthroscopy and/or by cartilage biopsy.

One question in need of further research is the correlation of arthroscopic findings and MRI-detected articular cartilage lesions. Many investigators feel that MRI lesions probably precede arthroscopic lesions (Martinelli 1995), but others have characterised such early MRI lesions as false positives (Reiser et al. 1988) since they cite arthroscopy as the current "gold standard" for detection of articular lesions. If MRI can discern differences in hyaline cartilage at the level of differentiating between articular cartilage zones (Lehner et al. 1989; Modl et al. 1991), then it is logical that MRI is probably more discerning as to the depth and extent of cartilage injury than is arthroscopy. In addition, the depth and breadth of articular cartilage lesions seem to be visualised earlier by MRI when not yet easily seen by arthroscopy (Sabiston et al. 1987), either due to the depth of the cartilage lesion and/or due to inaccessibility via arthroscopy of the area of interest of the joint.

\section{Disadvantages of MRI}

There are at least three significant barriers to adoption of more frequent use of MRI technology in equine medicine. First, current technology dictates that only disarticulated portions of the appendicular skeleton of horses can be imaged by MRI. Tables which can support the weight of adult horses must be custom-built, as has been done for computerised tomography at other institutions. Such tables will then allow in vivo imaging of appendicular skeleton, head, and cervical region in most adult horses. Second, there will remain a need for complete immobilisation during an MRI study. General anaesthesia will be required using current equipment. Third, the cost of MRI equipment is quite high, in part because older magnets are still in use in human medicine, thus diminishing the chances of obtaining useful MRI equipment at considerable savings as older, used equipment is discarded by human institutions. Currently, arthroscopy is considerably more affordable for routine use in equine lameness diagnosis.

\section{Future equine applications of MRI}

Current equine research efforts are two-fold. First, continued research is occurring with current technology, primarily on cadaver specimens as described above. Second, at least one commercial manufacturer is developing a portable "clam-shell" magnet for use in standing, sedated horses. Current technology has resulted in adequate but not ideal images using this device. The image capture time, however, remains at approximately $4 \mathrm{~min}$ and requires minimal patient movement for adequate images. Decreasing the capture time further will allow better images by decreasing the artefact caused by patient motion. The portable configuration of this magnet will allow imaging of distal appendicular skeleton, including feet, but no higher than the elbow and stifle regions.

\section{References}

Crass, J. R., Genovese, R. L., Render, J. A. and Bellon, E. M. (1992): Magnetic resonance, ultrasound and histopathologic correlation of acute and healing equine tendon injuries. Vet. Radiol. Ultrasound 33, 206-216.

Denoix, J. M., Crevier, N., Roger, B. and Lebas, J. F. (1993): Magnetic resonance imaging of the equine foot. Vet. Radiol. Ultrasound 34, 405-411.

Holcombe, S. J., Bertone, A. L., Biller, D. S. and Haider, V. (1995): Magnetic resonance imaging of the equine stifle. Vet. Radiol. Ultrasound 36, 119-125.

Kaser-Hotz, B., Sartoretti-Schefer, S. and Weiss, R. (1994): Computed tomography and magnetic resonance imaging of the normal equine carpus. Vet. Radiol. Ultrasound 35, 457-461.

Kean, D. M., Worthington, B. S., Preston, B. J., Roebuck, E. J., McKimThomas, H., Hawkes, R. C., Holland, G. N. and Moore, W. S. (1983): Nuclear magnetic resonance imaging of the knee: Examples of normal anatomy and pathology. British J. Radiol. 56, 355-364.

Lauterbur, P. C. (1973): Image formation of induced local interactions: Examples employing nuclear magnetic resonance. Nature 242, 190-191.

Lehner, K. B., Rechl, H. P., Gmeinwieser, J. K., Heuck, A. F., Lukas, H. P. and Kohl, H. P. (1989): Structure, function, and degeneration of bovine hyaline cartilage: Assessment with MR imaging in vitro. Radiol. 170, 495-499.

Martinelli, M. J. (1995): Magnetic resonance imaging of the equine metacarpophalangeal joint. M.S. Thesis, University of Illinois, Urbana, Illinois.

Modl, J. M., Sether, L. A., Haughton, V. M. and Kneeland, J. B. (1991): Articular cartilage: Correlation of histologic zones with signal intensity at MR imaging. Radiol. 181, 853-855.

Park, R. D., Nelson, T. R. and Hoopes, P. J. (1987): Magnetic resonance imaging of the normal equine digit and metacarpophalangeal joint. Vet. Radiol. 28, 105-116.

Reiser, M. F., Bongartz, G., Erlemann, R., Strobel, M., Pauly, T., Gaebert, K., Stoeber, U. and Peters, P. E. (1988): Magnetic resonance in cartilaginous lesions of the knee joint with three-dimensional gradient-echo imaging. Skeletal Radiol. 17, 564-471.

Sabiston, C. P., Adams, M. E. and Li, D. K. B. (1987): Magnetic resonance imaging of osteoarthritis: Correlation with gross pathology using an experimental model. J. Orthop. Res. 5, 164-172.

Schild, H. H. (1990): MRI made easy. H. Heenemann and Co., Berlin, pp. 1-105.

Weisman, I. D., Bennett, L. H., Maxwell, L. R., Woods, M. W. and Burk, D. (1972): Recognition of cancer in vivo by nuclear magnetic resonance. Science 178, 1288.

\section{Acknowledgements}

Equine MRI research at the University of Illinois has been previously funded in part by the Maria Caleel Fund for Equine Sports Medicine Research. The assistance of Dr. Robert Clarkson in reviewing this manuscript is gratefully acknowledged.

\section{Jonathan H. Foreman}

University of Illinois

College of Veterinary Medicine

Department of Veterinary Clinical Medicine

1008 West Hazelwood Drive

Urbana, Illinois 61801

USA

Phone:(217) 333-2000

Fax:(217) 244-1475

e-mail:jforeman@cvm.uiuc.edu 